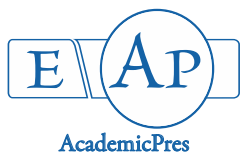

Sreelakshmy V et al. (2021)

Notulae Scientia Biologicae

Volume 13, Issue 2, Article number 10917

DOI: $10.15835 / \mathrm{nsb} 13210917$

Research Article

\title{
Salicylic acid pre-treatment induced physiological and biochemical changes in Solanum lycopersicum L. under salinity stress
}

\author{
Venu SREELAKSHMY, Gunasekar ANBARASI*, \\ Benaltraja VISHNUPRIYA
}

\author{
Kongunadu Arts and Science College, Bharathiar University, Coimbatore 641 029, Tamil Nadu, India; \\ sreelakshmyvenu9094@gmail.com; anbarasi.gk08@gmail.com (*corresponding author); vinubiotech28@gmail.com
}

\begin{abstract}
Agricultural crop production around the world is adversely affected by excess salt accumulation in the soil. Plants initiate broad range of signal transduction pathways to respond any stress. Salicylic acid (SA) is an endogenous plant growth regulator that acts as a signal molecule to modulate plant response by reducing the effects of abiotic stress on plants. The main objective of this study is to examine whether exogenous salicylic acid pre-treatment may reduce the adverse effects of salt stress and enhance salt tolerance in Solanum lycopersicum. For this experiment, two weeks old seedlings were subjected to salt stress by adding salt water $(100 \mathrm{mM} \mathrm{NaCl})$ for three days with or without salicylic acid pre-treatment. After salt stress exposure plant leaves were harvested and the various measures were recorded. Results of this study exhibited that salicylic acid pre-treatment mitigates various advers effects of salt stress on plant growth by stimulating plant biomass, water relations, protein content, chlorophyll pigment, and inorganic osmolytes accumulation. Simultaneously, an increase in activity of antioxidant enzymes of SOD, CAT and POX were also triggered. This current study suggested that pre-treating of Solanum lycopersicum with salicylic acid attenuates the depressive effect of salinity by accelerating the osmolyte accumulation and triggering activity of free radical scavenging enzymes.
\end{abstract}

Keywords: antioxidant enzymes; salicylic acid; salt stress; tomato

\section{Introduction}

Agricultural crop production around the world is severely limited by a variety of abiotic and biotic stresses. One of the most important abiotic factors that inhibited crop production was salt in arid and semiarid regions, where the salt content was naturally high and rainfall was insufficient to allow for leaching in soil (Zhao et al., 2007). Increased salinity affected nearly one-third of cultivated land (Kaya et al., 2002). Salt stress adversely affects the growth and productivity of cultivated plants. To cope with the altering climatic conditions, certain plants change their metabolism and activates variety of defence systems (Sticher et al., 1997). Although, certain plants involve in the mechanism of accumulation of compatible osmolytes such as proline and soluble sugar to overcome the salt stress (Shahba et al., 2010).

Plants respond to any stress by initiating a broad range of signal transduction pathways. Among the signalling molecules, salicylic acid (SA; o-hydroxybenzoic acid) is an endogenous plant growth substance

Received: 10 Mar 2021. Received in revised form: 27 May 2021. Accepted: 08 Jun 2021. Published online: 11 Jun 2021. From Volume 13, Issue 1, 2021, Notulae Scientia Biologicae journal uses article numbers in place of the traditional method of continuous pagination through the volume. The journal will continue to appear quarterly, as before, with four annual numbers. 
worked as a signal molecule involving in modulating plant response (Sing and Usha, 2003) and signal transducer (Senaratna et al., 2000). Through extensive signalling cross-talk with other growth hormones, salicylic acid also modulates different aspects of plant responses to abiotic stressors (Iqbal et al., 2015).

Many plant species can benefit from exogenous administration of SA to reduce toxicity symptoms caused by salt stress. Exogenously applied SA's ability to boost photosynthetic activity, enhance antioxidant protection by changing antioxidant enzyme activities, increase soluble carbohydrate accumulation, raise ATP content, and maintain an optimal $\mathrm{K}+/ \mathrm{Na}+$ ratio under saline circumstances has been proposed as potential mechanisms of salt tolerance in plants (Ashraf et al., 2010; Hayat and Ali, 2010).

Hence, this study was designed to evaluate the salicylic acid influences on amelioration of salt tolerance of plants by studying some physiological and metabolic significance in tomato (Solanum lycopersicum).

\section{Materials and Methods}

\section{Cultivation of plants}

Tomato seeds (Solanum lycopersicum) were planted at $2 \mathrm{~cm}$ depth in black polythene covers filled with vermicompost, soil and sand (1:2:1) (Figure 1). Growing seedlings were daily sprinkled with distilled water and maintained in green house.

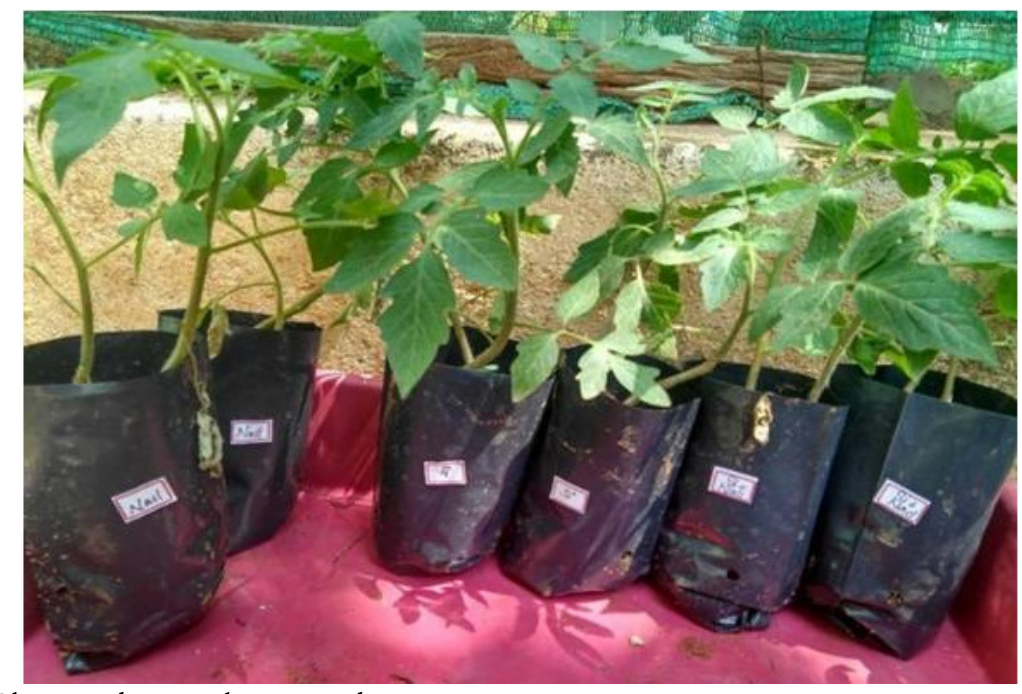

Figure 1. Plants under greenhouse condition

\section{Cultural conditions and treatment to the plants}

Two weeks old plants after the onset of third leaf, experiment was divided into four groups. Control: Control-Irrigated only with tap water for three days. SA: Salicylic acid treated-Irrigated with $80 \mathrm{mM}$ of salicylic acid for 3 days. $\mathrm{NaCl}$ : Stressed- Plants subjected with salt water $(100 \mathrm{mM} \mathrm{NaCl})$ for three days. $\mathrm{SA}+\mathrm{NaCl}$ : Pre-treated and stressed- Plants were treated with $80 \mathrm{mM} \mathrm{SA}$ for 3 days, after pre-treatment the same plants were again subjected with salt water for three days. Finally, after three days of salt exposure, all plants were harvested washed quickly with distilled water, blotted dried on filter papers and stored in deep freezer for future purpose. 


\section{Fresh and dry weight}

The leaf and root part of the plants were immediately separated cautiously after harvesting and was washed with distilled water and dried on absorbing paper in order to eradicate any additional salt surface contamination. The fresh weights $(\mathrm{FW})$ of the plants were calculated prior to oven drying at $70^{\circ} \mathrm{C}$ for $72 \mathrm{hrs}$ and their dry weights were recorded later.

\section{Relative Water Content ( $R W C$ )}

After determining the fresh weights, the samples were immersed in petri dish with distilled water for 24 hrs at $4{ }^{\circ} \mathrm{C}$ in darkness and the turgid weight (TW) was determined. The petri dishes were oven dried $\left(70^{\circ} \mathrm{C}\right.$ for $72 \mathrm{~h}$ ) and the dry weight (DW) was calculated. The RWC was calculated by following formula of RWC $(\%)=$ FW-RW/TW-DW $\times 100$ (Silveira et al., 2003).

\section{Chlorophyll content}

By following the method of Arnon (1949), Green pigment contents such as chlorophyll-a, chlorophyll$\mathrm{b}$ and total chlorophyll were measured by taking $200 \mathrm{mg}$ of fresh leaves were homogenized in $8 \mathrm{ml} 80 \%$ acetone with homogenizer. Then the homogenates were centrifuged at $4^{\circ} \mathrm{C}$ for $20 \mathrm{~min}$ at $3000 \mathrm{rpm}$. The separately collected supernatants used for the analysis of pigments. With spectrometer, the samples absorbance was determined at $645 \mathrm{~nm}, 652 \mathrm{~nm}$ and $663 \mathrm{~nm}$ respectively. The following equations were used for measuring the green pigment content (Litchtenthaler and Wellburn, 1983).

Total Chl: A652 $\times 27.8 \times 20 / \mathrm{mg}$ leaf weight

Chl-a: $(11.75 \times$ A663-2.35 $\times$ A645 $) \times 20 /$ mg leaf weight

Chl-b: $(18.61 \times$ A645-3.96 $\times$ A663 $) \times 20 /$ mg leaf weight

\section{Total free aminoacids}

Method of Moore and Stein (1948) was followed to estimate the total free amino acid content in the plant samples. The leaf tissues were treated with 80 percent of boiling ethanol for the purpose of obtaining extracts ( $5 \mathrm{ml}$ extract represents $1 \mathrm{~g}$ tissue). About one $\mathrm{ml}$ of the ethanol extract was taken in a $25 \mathrm{ml}$ test tube and was neutralized with $0.1 \mathrm{~N}$ sodium hydroxide using methyl red indicator. Additionally, one $\mathrm{ml}$ of ninhydrin reagent was added ( $800 \mathrm{mg}$ stannous chloride in $500 \mathrm{ml}$ citrate buffer ( $\mathrm{pH} 5.0$ ), $20 \mathrm{~g}$ ninhydrin in $500 \mathrm{ml}$ methylcellulose, both solutions were mixed). The mixture of above content was placed in a water bath and allowed to boil for 20 minutes and later $5 \mathrm{ml}$ of diluting solution (distilled water and $\mathrm{n}$-propanol mixed in equal volume) was added. The sample was then cooled and diluted up to $25 \mathrm{ml}$ with distilled water. The absorbance was measured at $570 \mathrm{~nm}$ in a spectrophotometer.

\section{Lipid peroxidation}

Methodology of thio-barbituric acid (TBA) reaction was tracked by following Buege and Aust (1978) for determining the level of lipid peroxidation by measuring the amount of malondialdehyde (MDA) released as a by product of lipid peroxidation in the samples. For this experiment, about $500 \mathrm{mg}$ of leaf material was homogenized in $5 \mathrm{ml}$ of $0.1 \%$ TCA and was centrifuged at 10,000 rpm for 5 minutes. For every $1 \mathrm{ml}$ of aliquot, $4 \mathrm{ml}$ of $20 \%$ TCA containing $0.5 \%$ thio-barbituric acid was added. The mixtures were kept at water bath at 95 ${ }^{\circ} \mathrm{C}$ for $30 \mathrm{~min}$. At last mixture was immediately transferred to ice bath for cooling. Finally, mixture was centrifuged at 10,000 rpm for 15 minutes. The amount of MDA in a supernatant was measured at $532 \mathrm{~nm}$.

\section{Proline content}

For the estimation of proline method of Bates et al. (1973) was followed. The leaf tissues of $500 \mathrm{mg}$ were taken and homogenised with $5 \mathrm{ml}$ of $3 \%$ aqueous sulphosalicylic acid and the homogenate was centrifuged for $10 \mathrm{~min}$ at $1000 \mathrm{Xg}$. One $\mathrm{ml}$ of collected extract supernatant was transferred into a fresh tube and $2 \mathrm{ml}$ of ninhydrin acid was mixed with extract. In addition, $2 \mathrm{ml}$ of glacial acetic acid was added and heated for 18 hours 
at $100^{\circ} \mathrm{C}$. Later, $4 \mathrm{ml}$ of toluene was used to extract the reaction mixture. The reaction mixture was well shaken and mixed by vertexing for 20-25 seconds. From the aqueous phase toluene-chromophore assortment was separated and the absorbance was measured at $520 \mathrm{~nm}$ in a spectrophotometer against toluene blank.

\section{Total protein extraction}

About $500 \mathrm{mg}$ of leaf was homogenized with $1 \mathrm{ml}$ of ice-cold extraction buffer which contains $100 \mathrm{mM}$ EDTA, $100 \mathrm{mM}$ tris ( $\mathrm{pH} 8.0$ ), $2 \%$ of $\beta$ mercaptoethanol $\mathrm{v} / \mathrm{v}, 50 \mathrm{mM}$ ascorbic acid, $30 \%$ sucrose $\mathrm{w} / \mathrm{v}, 50 \mathrm{mM}$ borax, $1 \%$ pvpp w/v and $1 \%$ triton $\mathrm{x}-100 \mathrm{v} / \mathrm{v}$. The above homogenate was vortexed at room temperature for 5 min. Further, two volumes of saturated phenol were added followed by gentle vertexing mixture was centrifuged for $10 \mathrm{~min}$ at $15000 \mathrm{rpm}$ at $4{ }^{\circ} \mathrm{C}$. Then the upper phase was transferred carefully into the fresh centrifuge tube and equal volume of ice-cold extraction buffer was added and centrifuged for $15000 \mathrm{rpm}$ for 15 $\min$ at $4{ }^{\circ} \mathrm{C}$. Again, the aqueous phase was transferred to fresh centrifuge tube and five volumes of methanol saturated with ammonium acetate was added and incubated at $-20^{\circ} \mathrm{C}$ for 6 hours for protein precipitation. After incubation the mixture was centrifuged, pellet was suspended and rinsed with ice cold methanol followed by ice cold acetone twice and spun down at $15000 \mathrm{rpm}$ for $5 \mathrm{~min}$ at $4{ }^{\circ} \mathrm{C}$. After each washing supernatant was decanted and Protein pellets were air dried. Finally, pellet retrieved with lysis buffer was maintained at $-80^{\circ} \mathrm{C}$ (Akshaya et al., 2018).

\section{Protein estimation}

Total protein concentration of the sample was determined by referring Bradford (1976). Bovine Serum Albumin was used $(1 \mu \mathrm{g} / \mu \mathrm{l})$ as a standard and the absorbance was recorded at $562 \mathrm{~nm}$.

\section{Estimation of superoxide dismutase activity (SOD)}

The SOD activity was determined by taking $550 \mu \mathrm{l}$ of $50 \mathrm{mM}$ phosphate buffer ( $\mathrm{pH} 7.4$ ), $38 \mu \mathrm{L}$ of 20 $\mathrm{mM} \mathrm{L}$-methionine, $20 \mu \mathrm{l}$ of Triton X-100, and $38 \mu \mathrm{l}$ of $10 \mathrm{mM}$ hydroxylamine hydrochloride, $50 \mu \mathrm{l}$ of EDTA and $50 \mu \mathrm{l}$ sample. This reaction mixture was incubated at $37^{\circ} \mathrm{C}$ for $5 \mathrm{~min}$ and $50 \mu \mathrm{l}$ of riboflavin was added into the mixture. Followed by the addition of riboflavin again it was incubated for 10 min under fluorescent lamp. After incubation mixture was finally added with $500 \mu \mathrm{l}$ of Griess reagent (1\% sulphanilamide, 2\% phosphoric acid and $0.1 \%$ Naphthalene diamine dihydrochloride). The formation of colour was recorded by taking absorbance at $543 \mathrm{~nm}$. One unit of the enzyme activity was defined as the amount of Superoxide dismutase required for inhibiting $50 \%$ of nitrate formation $\mathrm{min}^{-1} \mathrm{mg}^{-1}$ protein. The enzyme activities were measured twice for each sample replicate (Das et al., 2000).

\section{Estimation of catalase activity (CAT)}

The activity of catalase was measured by following the procedure of Sinha (1972). About $0.9 \mathrm{ml}$ of $0.01 \mathrm{M}$ potassium phosphate buffer $(\mathrm{pH} 7.0), 0.1 \mathrm{ml}$ of enzyme extract and $0.4 \mathrm{ml}$ of $0.2 \mathrm{M} \mathrm{H}_{2} \mathrm{O}_{2}$ were taken in the reaction tube. Enzyme-substrate reaction was stopped at 0 and after 60 seconds by the addition of $2 \mathrm{ml}$ of dichromate acetic acid mixture. After addition of inhibitor solution tubes were immediately kept in boiling water bath for 10min and then cooled. Colour development in the reaction mixture was read at $530 \mathrm{~nm}$. The catalase activity of the reaction mixture was calculated using the decreased in absorbance and molar extinction coefficient $\varepsilon=0.0436 \mu \mathrm{M}^{-1} \mathrm{~cm}^{-1}$ and expressed as $\mu \mathrm{M}$ of $\mathrm{H}_{2} \mathrm{O}_{2}$ utilized $\mathrm{g}^{-1} \mathrm{~min}^{1} \mathrm{mg}^{-1}$ protein. The enzyme activities were measured twice for each sample replicate.

\section{Estimation of peroxidase activity (POX)}

The enzyme activity of POX was carried out according to the method described by Neto et al. (2006). The reaction mixture for peroxidase assay consisted of $0.245 \mathrm{ml}$ of $1 \mathrm{M}$ phosphate buffer $(\mathrm{pH} 6.5), 0.25 \mathrm{ml}$ of $0.1 \mathrm{M}$ pyrogallol, $0.05 \mathrm{ml}$ of $100 \mathrm{mM}$ hydrogen peroxide, $0.01 \mathrm{ml}$ of enzyme extract and $1.36 \mathrm{ml}$ of distilled water. The reaction mixture was kept for incubation at $25^{\circ} \mathrm{C}$ for $5 \mathrm{~min}$ and further reaction was stopped by 
addition of $0.5 \mathrm{ml}$ of $10 \%$ (v/v) sulphuric acid. Absorbance was measured at $420 \mathrm{~nm}$ using UV-VIS spectrophotometer. Reaction mixture without enzyme extract served as blank. Enzyme activity of POX was calculated using molar extinction coefficient $\varepsilon=2.47 \times 10^{-3} \mu \mathrm{M}^{-1} \mathrm{~cm}^{-1}$ and expressed as $\mu \mathrm{M} \mathrm{min}^{-1} \mathrm{mg}^{-1}$ protein. The enzyme activities were measured twice for each sample replicate.

\section{Estimation of glutathione peroxidase activity (GPX)}

The activity of Glutathione peroxidase was assayed by following the procedure of Rotruck et al. (1973). This experiment was initiated by taking $100 \mu \mathrm{l}$ of $40 \mathrm{mM}$ phosphate buffer ( $\mathrm{pH} 7.4$ ), $50 \mu \mathrm{l}$ of $4 \mathrm{mM}$ EDTA, $25 \mu \mathrm{l}$ of $10 \mathrm{mM}$ sodium azide, $50 \mu \mathrm{l}$ of $4 \mathrm{mM}$ reduced glutathione, $25 \mu \mathrm{l}$ of $2.5 \mathrm{mM} \mathrm{H}_{2} \mathrm{O}_{2}$ and $50 \mu \mathrm{l}$ of sample. This mixture was incubated at $37^{\circ} \mathrm{C}$ for $10 \mathrm{~min}$. Then $125 \mu \mathrm{l}$ of $10 \%$ Trichloroacetic acid was added and incubated for $15 \mathrm{mins}$. After incubation $750 \mu \mathrm{l}$ of $30 \mathrm{mM}$ disodium hydrogen phosphate and $125 \mu \mathrm{l}$ of Ellman's reagent was added. Finally, the colour developed was read at $412 \mathrm{~nm}$ and the enzyme activity was expressed in terms of $\mu \mathrm{g}$ of glutathione utilized $\mathrm{min}^{-1} \mathrm{mg}^{-1}$ protein. The enzyme activities were measured twice for each sample replicate.

\section{Results and Discussion}

\section{Effects on fresh and dry weight}

The fresh and dry weight of leafs were measured after pre exposing and unimposing the plants to 80 mM SA for 3 days (Figure $2 \mathrm{a}$ and Figure $2 \mathrm{~b}$ ). Fresh and dry weight of leaf was significantly affected by high salinity stress $(100 \mathrm{mM} \mathrm{NaCl})$ by causing $42 \%$ and $37 \%$ decrease in fresh and dry weight of leaf. Whereas, salicylic acid pre-treatment diminishes salinity affects by increasing $42 \%$ and $25 \%$ of leaf fresh and dry weight. Neelam and Rahul, 2012 reported that salicylic acid applied Lycopersicon esculentum showed increased dry weight under salinity stress. Furthermore, Singh and Usha (2003) suggested that increase in dry mass of water stressed plants in response to salicylic acid related to the induction of antioxidant responses that protect the plant from damage.

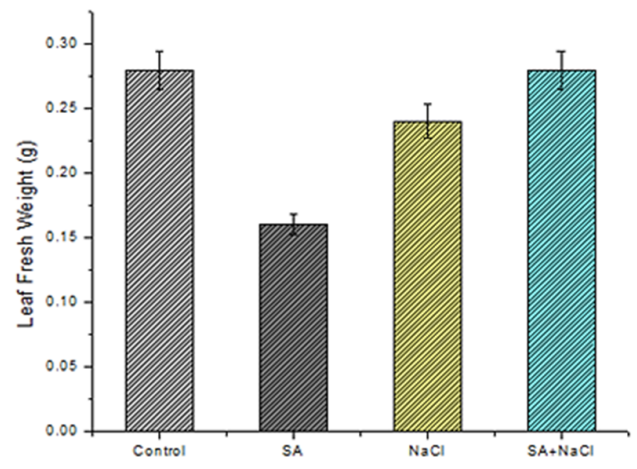

(a)

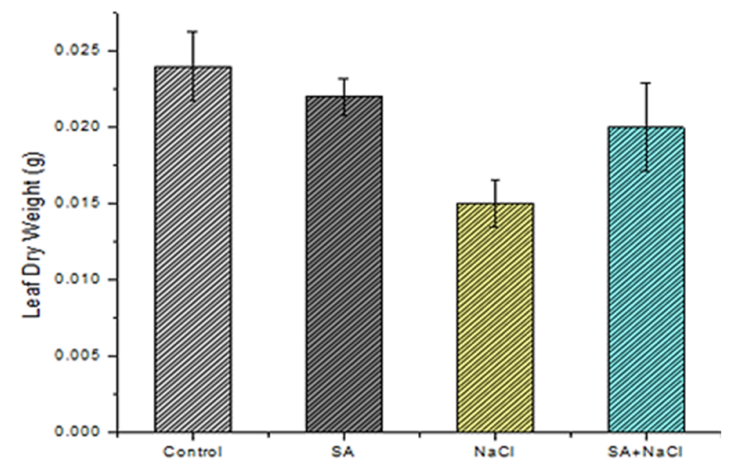

(b)

Figure 2. Leaf fresh weight (a) Leaf fresh weight of both individual and combined effect of salinity and SA. $\mathrm{X}$ axis-Treatment group; $\mathrm{Y}$ axis- fresh weight of leaves in gram. (b) Leaf dry weight of both individual and combined effect of salinity and SA. $\mathrm{X}$ axis-Treatment group; $\mathrm{Y}$ axis- Dry weight of leaves in gram Values are stated as mean $\pm S D, n=3$ in each group.

\section{Effects on relative water content}

Relative Water Content (RWC) is a key pointer of the degree of cell and tissue hydration. In the present study leaves of Solanum lycopersicum were showed highest RWC content in SA (96\%) followed by SA+NaCl treated samples (91\%) whereas under salinity stress plant leaf showed less RWC content of 79\%. Similar to 
present study, Tari et al. (2002) stated that exogenous SA treatment enhances RWC in leaves of tomato under salt stress. Hence, SA application may help in maintaining water status of plants by enhancing RWC to a marked level under salt stress represented in Figure 3.

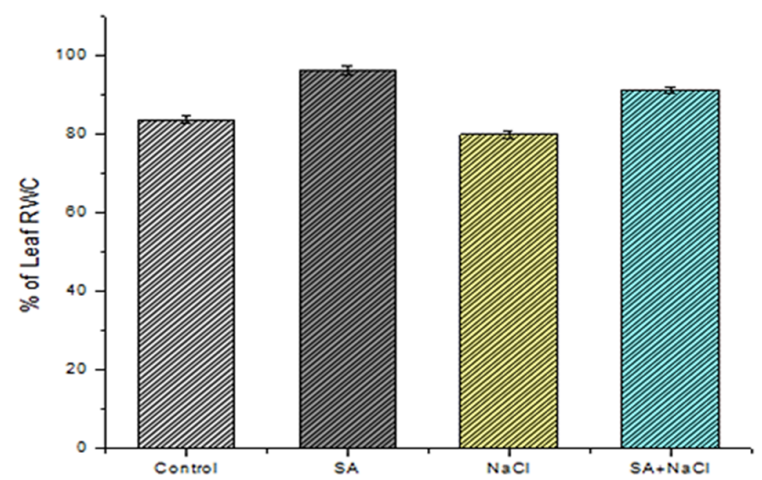

Figure 3. Relative Water Content (RWC): Relative water content of both individual and combined effect of salinity and SA. X axis-Treatment group; Y axis- Percentage of leaf RWC

Values are expressed as mean $\pm S D, n=3$ in each group.

\section{Effects on chlorophyll content}

The concentration of chlorophyll pigment 'a' was pointedly more in control $(26.21 \pm 1.54 \mathrm{mg} / \mathrm{FW})$ sample followed by SA $(23.44 \pm 1.27 \mathrm{mg} / \mathrm{FW})$ and $\mathrm{SA}+\mathrm{NaCl}(22.51 \pm 0.6 \mathrm{mg} / \mathrm{FW})$. It was considerably found in low concentration in $\mathrm{NaCl}(16.51 \pm 0.4 \mathrm{mg} / \mathrm{FW})$ compared to other treatments and control. The concentration of chlorophyll 'b' was found to be more in control $(55.52 \pm 0.74 \mathrm{mg} / \mathrm{FW})$ followed by SA $(42.21 \pm 1.01 \mathrm{mg} / \mathrm{FW})$. While treatment with $\mathrm{NaCl}$ resulted in low concentration of chlorophyll 'b' such as $23.73 \pm 1.42 \mathrm{mg} / \mathrm{FW}$. There was a significant increase was observed in SA pre-treatment $(42.42 \pm 1.59 \mathrm{mg} / \mathrm{FW})$. Total chlorophyll content found to be more in control followed by SA, $\mathrm{NaCl}$ and $\mathrm{SA}+\mathrm{NaCl}$ as $82.51 \pm 1.3$ $\mathrm{mg} / \mathrm{FW}, 64.53 \pm 0.8 \mathrm{mg} / \mathrm{FW}, 39.89 \pm 0.15 \mathrm{mg} / \mathrm{FW} 63.36 \pm 0.673 \mathrm{mg} / \mathrm{FW}$, respectively (Figure 4). Maryam et al. (2014) reported that pre-treatment of Lycopersicon esculentum with $1 \mathrm{mM}$ of salicylic acid following salinity stress caused significant increases in chlorophyll content. This current study results suggest SA treatment reduced the stress-induced loss in chlorophyll content.

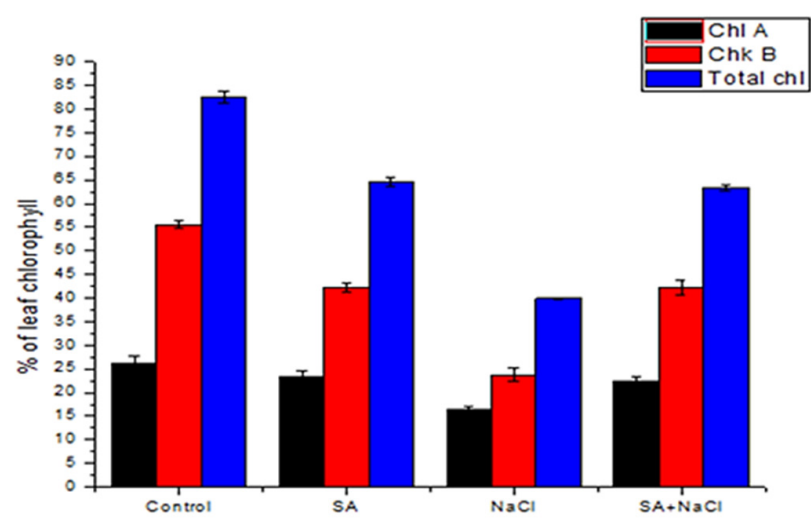

Figure 4. Chlorophyll content: individual and combined effect of salinity and SA on chlorophyll content. $\mathrm{X}$ axis-Treatment group; $\mathrm{Y}$ axis- Percentage of leaf chlorophyll pigments Values are expressed as mean $\pm S D, n=3$ in each group. 


\section{Effects on total free amino acid}

Accumulation of free amino acids is considered as an imperative factor for the majority of changes that occurs in osmotic potential and due to the hydrolysis of proteins. When compared to other treatment marked increase of total free amino acid level was reported in $\mathrm{NaCl}$ treated plants as $88 \mu \mathrm{g} / \mathrm{ml} \mathrm{FW}$ (Figure 5) and negligible amount of free amino acid accumulation was observed in salicylic acid pre-treatment. Thus, this current result indicates that protein degradation due to salt stress might be overcome by pre-treatment of plants with salicylic acid.

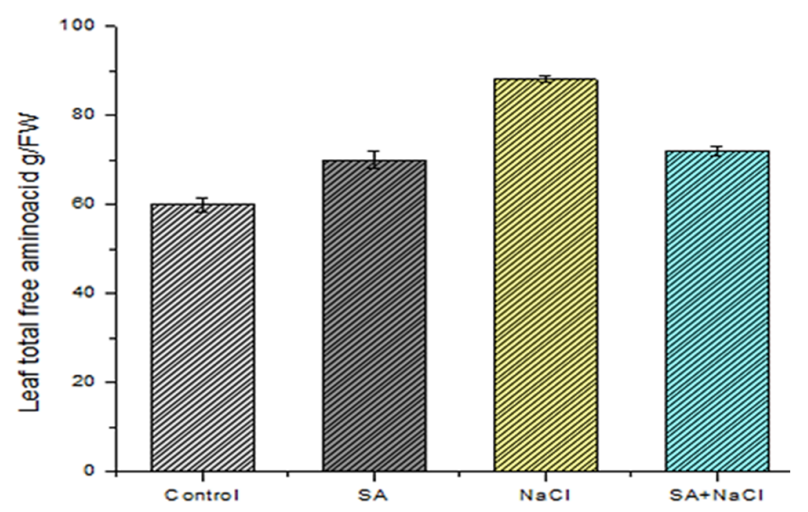

Figure 5. Leaf total free amino acid content: individual and combined effect of salinity and SA on leaf total free amino acid content. $\mathrm{X}$ axis -treatment group; $\mathrm{Y}$ axis - concentration of free amino acid (gram/ fresh weight)

Values are expressed as mean $\pm S D, n=3$ in each group.

\section{Effects on lipid peroxidation}

The malondialdehyde (MDA) production is considered as an indicator for membrane lipid peroxidation as a result of various stresses in plant membranes. A marked increase of MDA content was recorded in plants under salt stress. The leaves of Solanum lycopersicum treated with $\mathrm{NaCl}$ showed highest MDA content of $58 \mathrm{nmol} / \mathrm{ml}$ which showed $31 \%$ and $46 \%$ of increases than control and SA treated plants, respectively. Whereas, salicylic acid pre-treated plants exhibited 61\% reduction of MDA content (Figure 6). It has been suggested that $\mathrm{SA}$ application declined the rate of $\mathrm{H}_{2} \mathrm{O}_{2}$ production caused by salt stress in tomato plants.

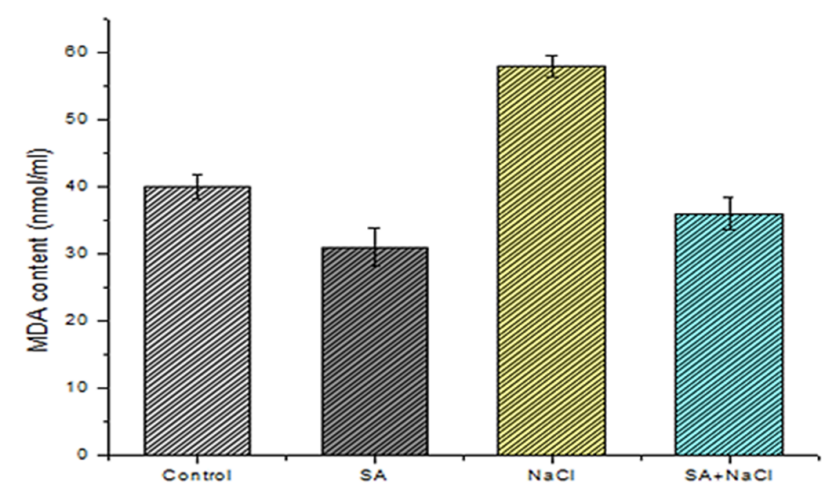

Figure 6. Leaf lipid peroxidation (MDA content): individual and combined effect of salinity and SA on leaf lipid peroxidation. $\mathrm{X}$ axis -treatment group; $\mathrm{Y}$ axis- concentration of MDA (nmol/ml)

Values are expressed as mean $\pm S D, n=3$ in each group. 


\section{Effects on proline content}

Accumulation of proline level increased significantly in salt stressed plants compared to SA pre-treated and control plants (Figure 7). Kadioglu et al. (2011) reported that salicylic acid treatment substantively increases the proline content of tomato plant under salt stress. Generally, accumulation of proline and its concentration has been shown to be more in plants affected by salinity stress to influences protein solvation and preserves the quaternary structure of complex proteins, maintains membrane integrity and reduces oxidation of lipid membranes or photo-inhibition (Demiral and Turkan, 2006).

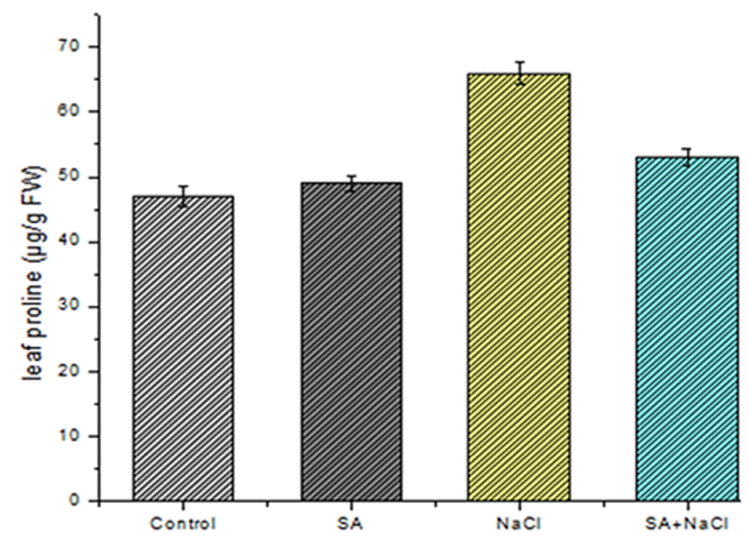

Figure 7. Leaf proline content: individual and combined effect of salinity and SA on leaf proline content. $\mathrm{X}$ axis -treatment group; $\mathrm{Y}$ axis - concentration of leaf proline ( $\mu \mathrm{g} / \mathrm{FW})$

Values are expressed as mean $\pm \mathrm{SD}, \mathrm{n}=3$ in each group.

\section{Effects on antioxidant enzymes}

The salicylic acid pre-treatments effects on tomato plants under salinity were monitored by assaying the activity of free radical scavenging enzymes such as Catalase, Glutathione Peroxidase, Superoxide Dismutase and Peroxidase. As a result of phytohormone pre-treatment changes in enzyme activity on plants under salt stress were shown in the Table 1 . Interaction of hormone and salinity on antioxidant enzymes were exhibited significant differences.

Table 1. Individual and combined effect of salinity and SA on antioxidant enzymes

\begin{tabular}{|l|c|c|c|c|}
\hline \multicolumn{1}{|c|}{ Group } & Control & SA & $\mathrm{NaCl}$ & SA+NaCl \\
\hline SOD & $0.23 \pm 0.03$ & $0.27 \pm 0.02$ & $0.15 \pm 0.01$ & $0.36 \pm 0.02$ \\
\hline CAT & $0.09 \pm 0.002$ & $0.07 \pm 0.003$ & $0.04 \pm 0.002$ & $0.08 \pm 0.002$ \\
\hline POX & $0.038 \pm 0.002$ & $0.058 \pm 0.006$ & $0.07 \pm 0.005$ & $0.097 \pm 0.003$ \\
\hline GPX & $0.131 \pm 0.003$ & $0.162 \pm 0.007$ & $0.15 \pm 0.007$ & $0.17 \pm 0.01$ \\
\hline
\end{tabular}

$S O D$

Activity of $\mathrm{SOD}$ in the leaf tissue of $\mathrm{SA}, \mathrm{SA}+\mathrm{NaCl}$ treated tomato plants were shown in Figure 8 . The tomato leaf tissues treated with $\mathrm{NaCl}$ showed decreased SOD activity than SA treated and control plants. The salicylic acid pre-treated plants exhibited more SOD activity than $\mathrm{NaCl}$ treated plants. The above finding indicates that salicylic pre-treatment protects the plants from damaging effects salinity stress. Hayat et al. (2010) admitted that SA enhanced the SOD activity in tomato plants under salinity stress. Similar enhanced SOD activity by SA treatment has been recorded in tomato grown under saline induced oxidative stress (Krantev et al., 2008). 


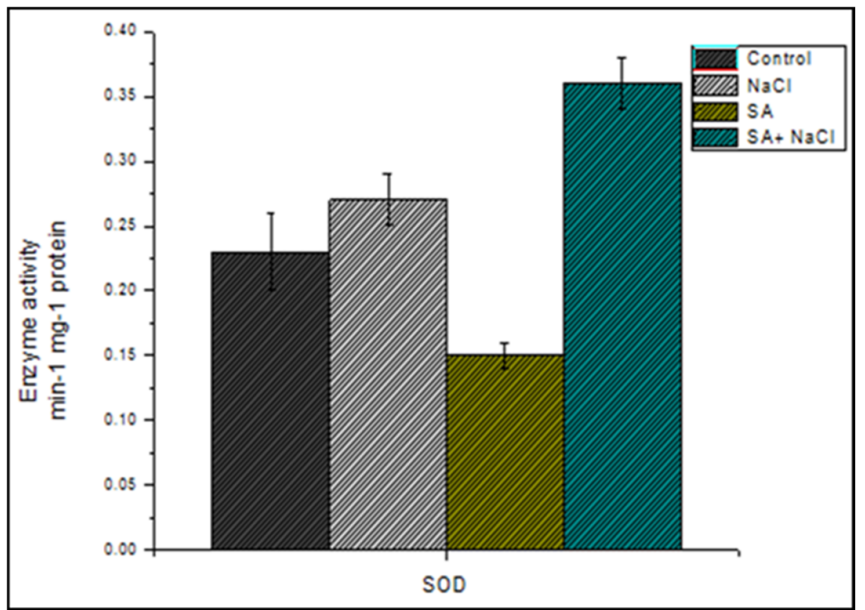

Figure 8. Superoxide dismutase activity: individual and combined effect of salinity and SA on leaf superoxide dismutase. $\mathrm{X}$ axis -treatment group; $\mathrm{Y}$ axis - enzyme activity ( $\mathrm{min}^{-1} \mathrm{mg}^{-1}$ protein) Values are expressed as mean $\pm S D, n=3$ in each group.

\section{CAT}

The stimulation effect of catalase enzyme by the interaction between salicylic acid pre-treatment and salinity were shown in Figure 9. The highest value of catalase activity was recorded at control followed by salicylic acid treated leaves. The $\mathrm{NaCl}$ treated plants exhibited least catalase activity. Whereas, pre exposing the plant with salicylic acid before salinity resulted in increased CAT activity as compared with unexposed plants.

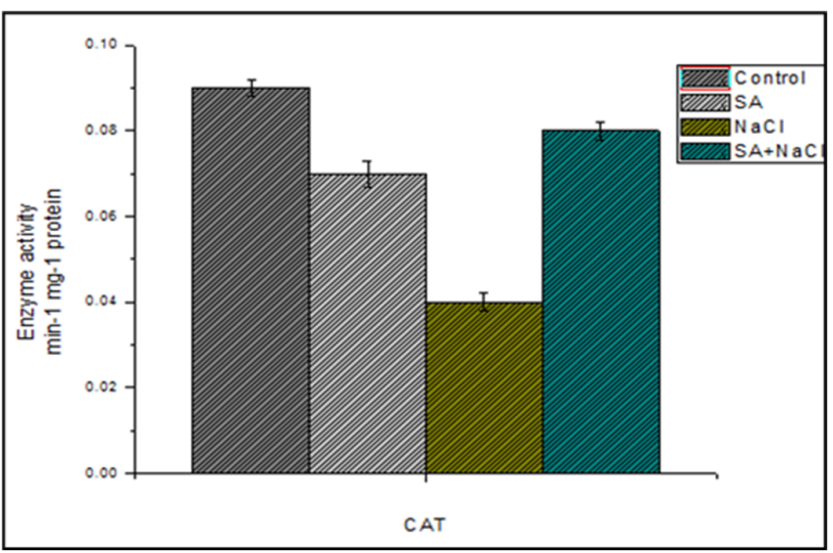

Figure 9. Catalase activity: individual and combined effect of salinity and SA on catalase activity. X axis treatment group; $\mathrm{Y}$ axis - enzyme activity $\left(\mathrm{min}^{-1} \mathrm{mg}^{-1}\right.$ protein)

Values are expressed as mean $\pm \mathrm{SD}, \mathrm{n}=3$ in each group.

\section{POX}

Changes in the activity of peroxidase enzyme as the result of $\mathrm{NaCl}$ and $\mathrm{SA}+\mathrm{NaCl}$ treatment on tomato plant were shown in Figure 10. Plants which are pre-treated with SA showed increased POX activity than the $\mathrm{NaCl}, \mathrm{SA}$ and control. This study result indicates that plants treated with SA might be reducing the level oxidative damage caused by high salinity stress. 


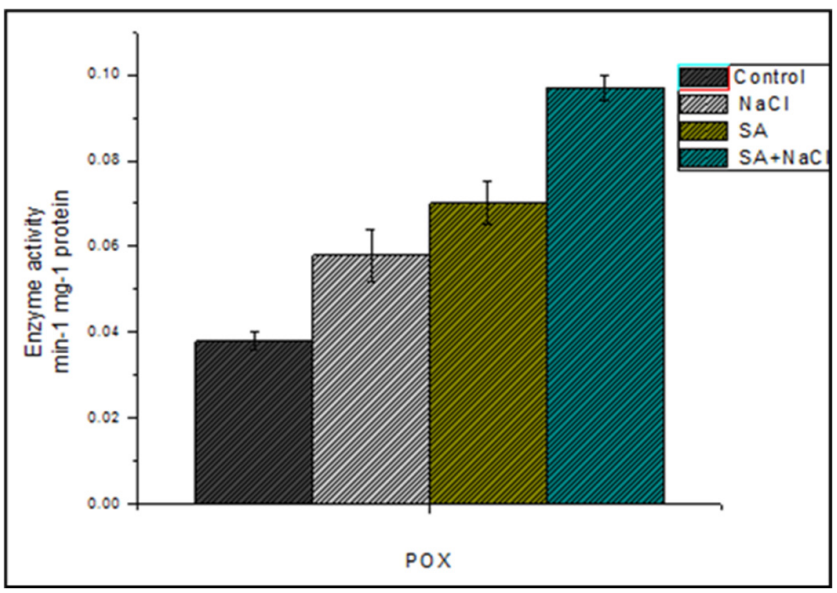

Figure 10. Peroxidase activity: individual and combined effect of salinity and SA on peroxidase activity. X axis -treatment group; $\mathrm{Y}$ axis - enzyme activity $\left(\mathrm{min}^{-1} \mathrm{mg}^{-1}\right.$ protein $)$

Values are expressed as mean $\pm S D, n=3$ in each group.

\section{$G P X$}

Glutathione peroxidase enzyme level in the leaf tissue of Control, $\mathrm{SA}, \mathrm{NaCl}$ and $\mathrm{SA}+\mathrm{NaCl}$ treated tomato plants were shown in Figure11. There was a significant change in the enhancement of GPX enzyme was observed between salt stressed and SA pre-treated treated plants.

Overall salt induced negative effects were significantly diminished by enhanced GPX activity by salicylic acid pre-treatment.

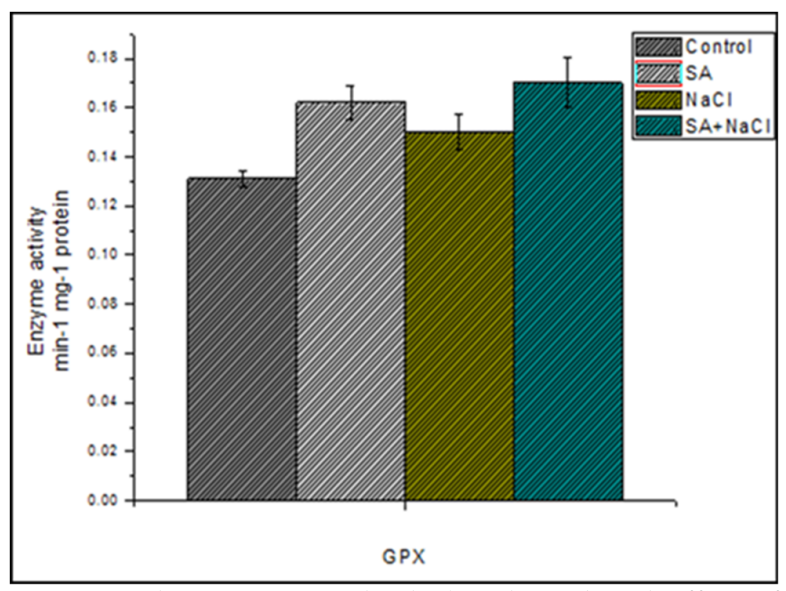

Figure 11. Glutathione peroxidase activity: individual and combined effect of salinity and SA on glutathione peroxidase activity. $\mathrm{X}$ axis - treatment group; $\mathrm{Y}$ axis- enzyme activity ( $\mathrm{min}^{-1} \mathrm{mg}^{-1}$ protein) Values are expressed as mean $\pm \mathrm{SD}, \mathrm{n}=3$ in each group. 


\section{Conclusions}

Overall, this current study shows that pre-treating the Tomato (Solanum lycopersicum L) with exogenous pre-treatment of $80 \mathrm{mM}$ salicylic acid substantially influence considerable protection against salinity stress through balancing relative water content, free aminoacid and MDA content as well as proline and antioxidant enzymes. Salicylic acid's ability to protect plants against salt stress may be due to its effects on $\mathrm{Na}+$ and $\mathrm{K}+$ uptake, as well as an increase in the amount of chlorophyll, which is required for several metabolic processes. As a result, exogenously applied salicylic acid reduced external osmotic potential and ion toxicity, suggesting that it may be useful in reducing the negative consequences of salt stress. The findings show that the salt tolerance level of the plants was increased by pre-treatment of exogenous salicylic acid.

\section{Authors' Contributions}

Study conception, design and acquisition of data done by GA; Analysis and interpretation of data by AVS; Drafting of manuscript by GA, AVS, VB; Critical revision done by VB.

All authors read and approved the final manuscript.

\section{Acknowledgements}

The authors like to thank Kongunadu Arts and Science College and DST-FIST for providing laboratory facilities.

\section{Conflict of Interests}

The authors declare that there are no conflicts of interest related to this article.

\section{References}

Akshaya M, Arun Kumar, Anbarasi G, Indhumathi A, Kaarunya E, Balasubramanian T, Somasundaram T (2016). Hsp70 and Theta subunit of T complex protein, a response to salt stress in the halophyte Sesuvium portulacastrum. Journal of Bioinformatics and Proteomics Review 2:1-9. https://doi.org/10.15436/2381-0793.16.010

Arnon D (1949). Copper enzymes in isolated chloroplasts. Polyphenoloxidase in Beta vulgaris. Plant Physiology 24:1-15. https://doi.org/10.1104/pp.24.1.1

Ashraf MA, Ashraf M, Ali Q (2010). Response of two genetically diverse wheat cultivars to salt stress at different growth stages: leaf lipid peroxidation and phenolic contents. Pakistan Journal of Botany 42:559-565.

Bates LS, Waldren RP, Teare ID (1973). Rapid determination of free proline for waste stress studies. Plant and Soil 39:205-207. https://doi.org/10.1007/BF00018060

Bradford MM (1976). Rapid and sensitive method for the quantitation of microgram quantities of protein utilizing the principle of protein-dye binding. Analytical Biochemistry 72:248-254. https://doi.org/10.1016/00032697(76)90527-3

Buege JA, Aust SD (1978). Microsomal lipid peroxidation. Methods in Enzymology 52:302-310. https://doi.org/10.1016/s0076-6879(78)52032-6

Das K, Samanta L, Chainy GBN (2000). A modified spectrophotometric assay of superoxide dismutase using nitrite formation by superoxide radicals. Indian Journal of Biochemistry and Biophysics 37:201-204. 
Demiral T, Türkan I (2006). Exogenous glycinebetaine affects growth and proline accumulation and retards senescence in two rice cultivars under $\mathrm{NaCl}$ stress. Environmental and Experimental Botany 56:72-79. https://doi.org/10.1016/j.envexpbot.2005.01.005.

Hayat Q, Hayat S, Irfan M, Ahmad A (2010). Effect of exogenous salicylic acid under changing environment: a review. Environmental and Experimental Botany 68:14-25. https://doi.org/10.1016/j.envexpbot.2009.08.005

Hayat R, Ali S. Nitrogen fixation of legumes and yield of wheat under legumes-wheat rotation in Pothwar. Pakistan Journal of Botany 42(3):in press.

Iqbal M, Khan R, Meharfatma, Khan A (2015). Salicylic acid induced abiotic stress tolerance and underlying mechanisms in plants. Frontiers in Plant Science 6:462. https://doi.org/10.3389/fpls.2015.00462.

Kadioglu A, Saruhan N, Saglam A (2011). Exogenous salicylic acid alleviates effects of long-term drought stress and delays leaf rolling by inducing antioxidant system. Plant Growth Regulation 64:27-37. https://doi.org/10.1007/s10725010-9532-3

Kaya C, Higgs D, Saltali K, Gezeral O (2002). Response of strawberry grown at high salinity and alkalinity to supplementary potassium. Journal of Plant Nutrition 25(7):1415-1427. https://doi.org/10.1081/PLN120005399.

Krantev A, Yordanova R, Janda T, Szalai G, Popova L (2008). Treatment with salicylic acid decreases the effect of cadmium on photosynthesis in maize plants. Journal of Plant Physiology 165:920-931. https://doi.org/10.1016/j.jplph.2006.11.014.

Lichtenthaler HK, Wellburn AR (1983). Determinations of total carotenoids and chlorophylls a and b of leaf extracts in different solvents. Biochemical Society Transactions 11:591-592.

Maryam H, Kambiz M, Farshid Ghaderifar, Seyyed JM (2014). Tomato morphological and biochemical characteristics in response to foliar applying of salicylic acid. International Journal of Biosciences 5(9):237-243. http://dx.doi.org/10.12692/ijb/5.9.237-243

Moore OS, Stein W (1948). Photoetricninhydrine method for use in the chromatography of amino acids. The Journal of Biological Chemistry 17:367-388.

Neelam M, Rahul M (2012). Salicylic acid changes plant growth parameters and proline metabolism in Rauwolfia serpentina leaves grown under salinity stress. American Eurasian Journal of Agricultural \& Environmental Sciences 12(12):1601-1609. http://dx.doi.org/10.5829/idosi.aejaes.2012.12.12.1919

Neto ADD, Prisco JT, Eneas-filho J, Braga de Abreu CE, Gomes-filho E (2006). Effect of salt stress on antioxidative enzymes and lipid peroxidation in leaves and roots of salt tolerant and salt sensitive maize genotypes. Environmental and Experimental Botany 56(1):87-94. https://doi.org/10.1016/j.envexpbot.2005.01.008

Rotruck JT, Pope AL, Ganther HL, Swanson AB, Hafeman DG, Hoekstra WG (1973). Selenium: biochemical role as a component of glutathione peroxidase. Science 179(4073):588-90.

Senaratna T, Touchell D, Bunn E, Dixon K (2000). Acetyl salicylic acid(aspirin) and salicylic acid induce multiple stress tolerance in bean and tomato plants. Plant Growth Regulation 30:157-161. https://doi.org/10.1023/A:1006386800974.

Shahbaz M, Ashraf M, Akram NA, Hanif A, Hameed S, Joham S, Rehman R (2010). Salt induced modulation in growth, photosynthetic capacity, proline content and ion accumulation in sunflower (Helianthus annuus L.). Acta Physiologiae Plantarum 33:1113-1122.

Silveira LF, Olmos F, Rodaand SA, Long AJ (2003). Notes on the seven coloured tanager Tanager fastuosa in north east Brazil. Cotinga 20:82-88.

Singh B, Usha K (2003). Salicylic acid induced physiological and biochemical changes in wheat seedlings under water stress. Plant Growth Regulation 47:389-394. https://doi.org/10.1023/A:1022556103536

Sticher L, Mauch-Mani B, Meltraux JP (1997). Systemic acquired resistance. Annual review of plant pathology 35:235270. https://doi.org/10.1146/annurev.phyto.35.1.235

Tari I, Csiszar J, Szalai G, Horvath F, Pecsvaradi A, Kiss G, Szepesi A, Szabo M, Erdei L (2002). Acclimation of tomato plants to salinity stress after a salicylic acid pre-treatment. Acta Biologica Szegediensis 46:55-56. http://www.sci.uszeged.hu/ABS

Zhao J, Ren W, Zhi D, Wang L, Xia G (2007). Arabidopsis DREB1A/CBF3 bestowed transgenic tall rescue increased tolerance to drought stress. Plant Cell Reports 26:1521-1528. https://doi.org/10.1007/s00299-007-0362-3 
OPEN ACCESS The journal offers free, immediate, and unrestricted access to peer-reviewed research and scholarly work. Users are allowed to read, download, copy, distribute, print, search, or link to the full texts of the articles, or use them for any other lawful purpose, without asking prior permission from the publisher or the author.

(C) (9)

License - Articles published in Notulae Scientia Biologicae are Open-Access, distributed under the terms and conditions of the Creative Commons Attribution (CC BY 4.0) License.

(c) Articles by the authors; SHST, Cluj-Napoca, Romania. The journal allows the author(s) to hold the copyright/to retain publishing rights without restriction. 